Provided for non-commercial research and education use. Not for reproduction, distribution or commercial use.

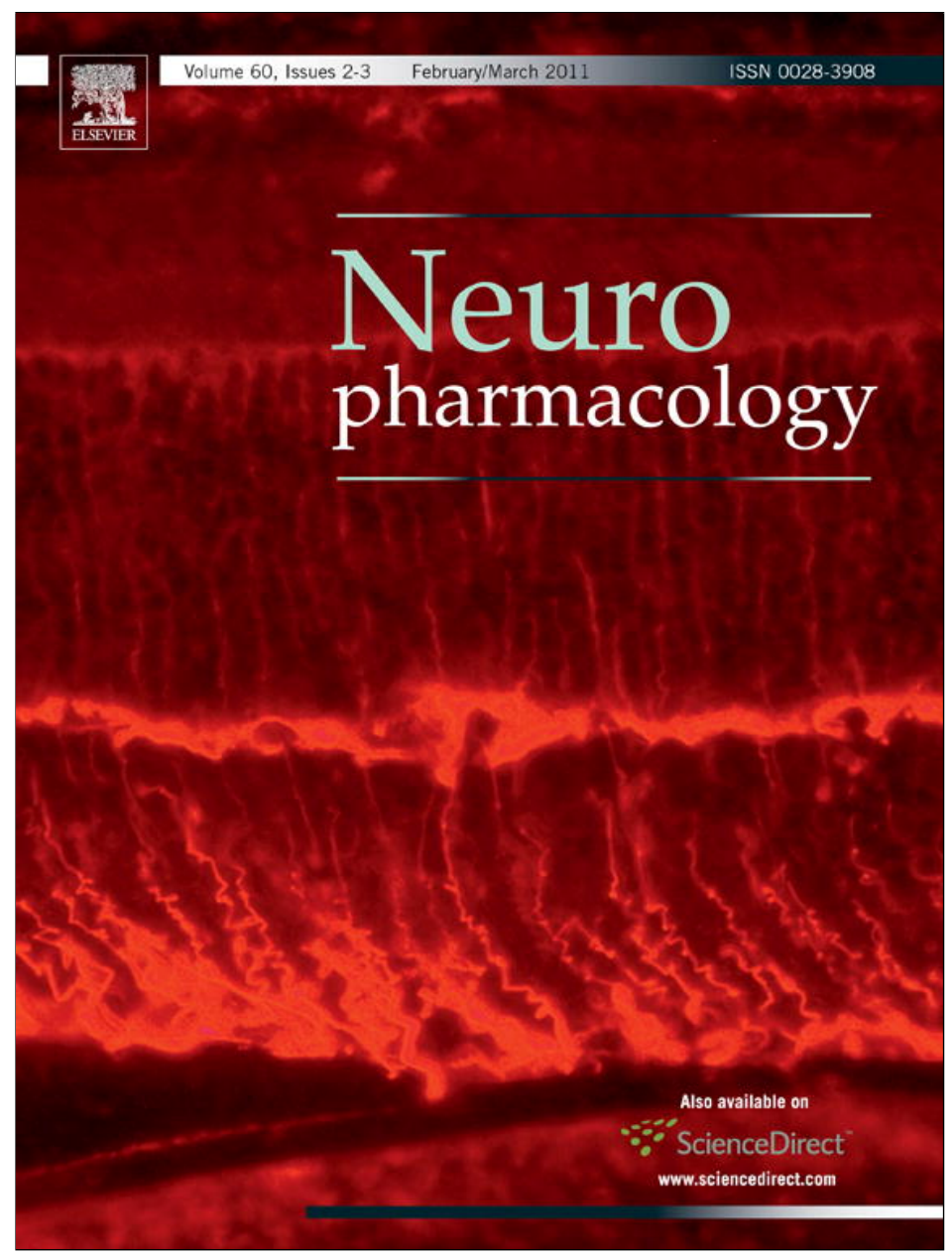

This article appeared in a journal published by Elsevier. The attached copy is furnished to the author for internal non-commercial research and education use, including for instruction at the authors institution and sharing with colleagues.

Other uses, including reproduction and distribution, or selling or licensing copies, or posting to personal, institutional or third party websites are prohibited.

In most cases authors are permitted to post their version of the article (e.g. in Word or Tex form) to their personal website or institutional repository. Authors requiring further information regarding Elsevier's archiving and manuscript policies are encouraged to visit:

http://www.elsevier.com/copyright 


\title{
Potentiation and inhibition of glycine receptors by tutin
}

\author{
Jorge Fuentealba ${ }^{\mathrm{a}, *, 1}$, Braulio Muñoz ${ }^{\mathrm{a}, 1}$, Gonzalo Yévenes $^{\mathrm{b}}$, Gustavo Moraga-Cid $^{\mathrm{b}}$, Claudia Pérez ${ }^{\mathrm{c}}$, \\ Leonardo Guzmán ${ }^{\mathrm{b}}$, Jean Michel Rigo ${ }^{\mathrm{d}}$, Luis G. Aguayo ${ }^{\mathrm{b}}$ \\ ${ }^{a}$ Neuroactive Drugs Screening Unit, Department of Physiology, Faculty of Biological Sciences, University of Concepción, Chile \\ ${ }^{\mathrm{b}}$ Laboratory of Neurophysiology, Department of Physiology, Faculty of Biological Sciences, University of Concepción, Chile \\ ${ }^{c}$ Chemistry Laboratory of Natural Products, Department of Botany, Faculty of Natural and Oceanographic Sciences, University of Concepción, Chile \\ ${ }^{\mathrm{d}}$ Laboratory of Cell Physiology, BIOMED Research Institute, University of Hasselt, Belgium
}

\section{A R T I C L E I N F O}

\section{Article history:}

Received 20 May 2010

Received in revised form

21 October 2010

Accepted 25 October 2010

\section{Keywords:}

Tutin

Glycine receptor

Ethanol

$\mathrm{Zn}^{2+}$

$\mathrm{GABA}_{\mathrm{A}}$ receptor

Picrotoxin

\begin{abstract}
A B S T R A C T
In the present study we characterized the effects of the South American neurotoxin tutin on recombinant glycine receptors (GlyR) expressed in HEK 293 cells using whole-cell patch-clamp techniques. Tutin induced a concentration-dependent inhibition of $\alpha_{1}$ and $\alpha_{2}$ homomeric GlyRs, with IC ${ }_{50}$ s of $35 \pm 1$ and 15 $\pm 3 \mu \mathrm{M}$, respectively. The co-expression of $\alpha \beta$ subunits reduced the potency of tutin, thus increasing the IC $_{50}$ to $51 \pm 4$ and $41 \pm 8 \mu \mathrm{M}$ for $\alpha_{1} \beta$ and $\alpha_{2} \beta$ GlyRs, respectively. The inhibitory effect of tutin was competitive, independent of membrane potential and reversible suggesting a pore independent site. On the other hand, low tutin concentrations enhanced the current, which was not synergic with $\mathrm{Zn}^{2+}$ or ethanol. A mutation in Lys385 altered ethanol but not tutin sensitivity, suggesting different sites for modulation of $\alpha 1$-containing GlyRs. Our results suggest that tutin affects the GlyR by a mechanism distinct to that of picrotoxin and ethanol, and that the pharmacological profile of tutin exhibits a " $\mathrm{Zn}$ like" behaviour. In conclusion, these results provide information on molecular mechanisms important for understanding the toxic effects of a recently discovered South American neurotoxin.
\end{abstract}

(C) 2010 Elsevier Ltd. All rights reserved.

\section{Introduction}

Tutin, a picrotoxane molecule, is a poisonous compound recently isolated from Coriaria ruscifolia subspecie ruscifolia, a native shrub from the southernmost region of Chile, that is known for having marked neurotoxic properties in humans and that can lead to death (Hoffmann, 1982; Garcia Martin et al., 1983). Extracts from Coriariaceae have been used in Chinese traditional medicine to treat mental disease, with seizures being observed in a few patients (Wang et al., 2003). Interestingly, the structure of tutin has many similarities to picrotoxin (Kudo et al., 1984), and animal toxicity studies showed that rodents experienced muscle spasms, seizures and respiratory paralysis (Fuentealba et al., 2007). We recently characterized the inhibitory effects of tutin, at doses of milligram $/ \mathrm{Kg}$, on native glycine and $\mathrm{GABA}_{\mathrm{A}}$ receptors in spinal neurons.

\footnotetext{
* Corresponding author. Neuroactive Drugs Screening Unit, Department of Physiology, Faculty of Biological Sciences, University of Concepcion, Barrio Universitario s/n, PO Box 160-C, Concepcion, Chile. Tel.: +56 41 2207318; fax: +56 42 2245975.

E-mail address: jorgefuentealba@udec.cl (J. Fuentealba).

1 Equal contribution.
}

Glycine and GABA are main neurotransmitters mediating fast inhibitory neurotransmission (Aguayo et al., 2004; Muller et al., 2008; Lynch, 2009). GlyRs, as well as $\mathrm{GABA}_{A} R s$, belong to the cys-loop ligand-gated channel (LGIC) superfamily (Cleland, 1996; Cully et al., 1996; Aguayo et al., 2004; Lynch, 2004) and display a pentameric structure containing a central pore permeable to $\mathrm{Cl}^{-}$ (Barnard et al., 1998; Bormann, 2000; Legendre, 2001; Lynch, 2004; Maksay and Biro, 2005; Janssen et al., 2007). GlyRs are competitively inhibited by the convulsant alkaloid strychnine (Akaike and Kaneda, 1989; Betz, 1991; Bechade et al., 1994) with an $\mathrm{IC}_{50}$ in the nanomolar range. On the other hand, low concentrations of $\mathrm{Zn}^{2+}$ or ethanol, acting at different sites, can induce a positive modulation on GlyR function (Aguayo and Pancetti, 1994; Bloomenthal et al., 1994; Suwa et al., 2001; Miller et al., 2005a; Miller et al., 2005b). Picrotoxin (PTX), on the other hand, was suggested to act as a GlyR blocker through a use-independent manner (Lynch et al., 1995), whereas it appeared to inhibit $\mathrm{GABA}_{\mathrm{A}}$ Rs through a use-dependent fashion (Newland and CullCandy, 1992). Also, it was suggested that PTX can bind to specific sites within the GlyR channel (Wang et al., 2007). On the other hand, the actions of tutin at the receptor level are largely unknown. Therefore, we studied the effect of tutin on recombinant homomeric and heteromeric GlyRs. 


\section{Materials and methods}

2.1. Tutin isolation

Tutin was isolated from dried leaves of Coriaria ruscifolia locally collected (Concepción, Chile) and the purification has been previously described (Fuentealba et al., 2007). In brief, the final purification was made from chloroformic and ethy acetate portions and the purity (>99\%) was assayed with ${ }^{1} \mathrm{H}$ NMR and ${ }^{13} \mathrm{C}$ NMR.

\subsection{HEK Cell culture and transfection}

HEK 293 cells were cultured using standard methodologies and transfected with lipofectamine 2000 (Invitrogen) in presence of the PCI vector containing the genes for glycine $\alpha_{1}, \alpha_{2}$ and $\beta$ subunits and GFP. Recordings were done $18-24 \mathrm{~h}$ after transfection. When the heteromeric receptors were expressed, a 1:3 ( $\alpha: \beta$ for GlyR) ratio was used to increase the probability of successful co-expression.

\subsection{Electrophysiological recordings in HEK cells}

Voltage-clamp recordings were performed in the whole-cell configuration of the patch-clamp technique and acquired with an Axon 200-B amplifier (Molecular Devices). Patch-clamp microelectrodes were filled with an internal solution containing (in mM): $140 \mathrm{KCl}, 10$ BAPTA, 10 HEPES (pH 7.4), $4 \mathrm{MgCl}_{2}, 0.3 \mathrm{GTP}$ and 2 ATP$\mathrm{Na}_{2}, 300$ mOSM. The external solution contained (in $\mathrm{mM}$ ): $150 \mathrm{NaCl}, 5.4 \mathrm{KCl}, 2.0$ $\mathrm{CaCl}_{2}, 1.0 \mathrm{MgCl}_{2}, 10 \mathrm{HEPES}$ ( $\mathrm{pH} 7.4$ ) and 10 glucose. The holding potential was fixed at $-60 \mathrm{mV}$ and recordings were filtered at $5 \mathrm{kHz}$ with a low pass Bessel filter. The working solutions were prepared daily from the stock. The recordings were made by applying short pulses $(1 \mathrm{~s})$ of glycine every $1 \mathrm{~min}$ with a perfusion system. After stabilizing the current amplitude, tutin was co-applied with the agonists and the amplitude of the current was measured. We applied a full range of tutin concentrations $(0.001-1000 \mu \mathrm{M})$ to single cells in order to obtain a concentration-response curve. In these experiments, glycine was applied for $1 \mathrm{~s}$ each $1 \mathrm{~min}$, and tutin was co-applied with glycine during the same time interval after control application. The voltage-current relationship was made by measuring the peak current in the presence of glycine alone or co-applied with tutin in the same cell; the holding potential was incremented by $10 \mathrm{mV}$ from -60 to $+30 \mathrm{mV}$ each $1 \mathrm{~min}$.

\subsection{Data analysis}

Data are expressed as mean \pm SEM. Statistical comparisons were performed using Student's $t$-test or ANOVA. $P<0.05$ was considered significant. All the curves were fitted with the Hill equation and the $\mathrm{IC}_{50} \mathrm{~s}$ were calculated using Origin 8.0 software (Origin Lab. Corporation). The data was fit assuming a single inhibitory binding site isotherm, thus excluding all concentrations that produced current potentiation.

\section{Results}

\subsection{Inhibition of homomeric $\alpha_{1}$ and $\alpha_{2}$ GlyRs by tutin}

We first examined the effects produced by tutin $(0.001-1000 \mu \mathrm{M})$ on $\alpha_{1}$ and $\alpha_{2}$ homomeric GlyRs using an equipotent concentration of glycine $\left(\mathrm{EC}_{50}\right.$ for each receptor subtype: $\alpha_{1}=27 \pm 3$ and $\left.\alpha_{2}=90 \pm 7 \mu \mathrm{M}\right)$. Fig. 1 shows the effect of several concentrations of tutin on homomeric $\alpha_{1}$ receptors (Fig. 1A, and closed circles in Fig. 1B). At concentrations above $1 \mu \mathrm{M}$, tutin caused a concentration-dependent inhibition on the amplitude of the glycine current, causing a complete blockade at the highest concentration tested $(1000 \mu \mathrm{M})$. Interestingly, tutin enhanced the amplitude of the current at lower concentrations, especially in the $\alpha 1$ subunit $(30,1000 \mathrm{nM})$. The $\alpha_{2}$ homomeric receptor, on the other hand, displayed a higher sensitivity to tutin inhibition than $\alpha_{1}$ (Fig. 1B, open circles). Analysis of the data showed that the apparent $\mathrm{IC}_{50}$ for the inhibition of $\alpha_{2}$ monomeric receptors by tutin was $15 \pm 3 \mu \mathrm{M}$ (Table $1, n=6$ ), while the corresponding value for $\alpha_{1}$ monomeric receptors was significantly higher at $35 \pm 1 \mu \mathrm{M}$ $(p<0.05, n=8)$. We also found that the extent of inhibition was similar with co-application of glycine and tutin or pre application of tutin (not shown). Using low concentrations of tutin $(\leq 1 \mu \mathrm{M})$, we found that it increased the amplitude of the current above the control value in both $\alpha_{1}(30 \pm 4 \%, p<0.01)$ and $\alpha_{2}(16 \pm 9 \%$, $p<0.05$, Table 2 ) subunits. Additional analysis in $\alpha 1$ showed that an
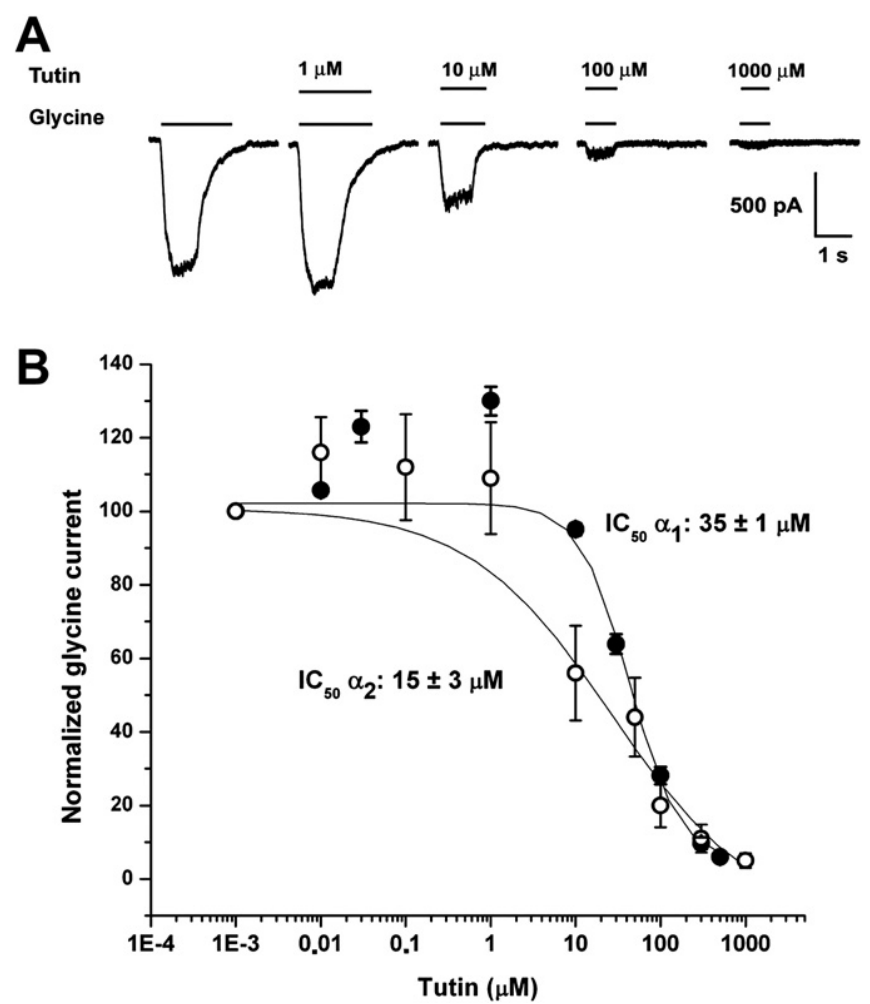

Fig. 1. Inhibitory effects of tutin in homomeric GlyRs. A, the current traces were evoked by glycine $(27 \mu \mathrm{M})$ on $\alpha 1$ GlyRs alone and in presence of several tutin concentrations. B, the curves are concentration-response relationships for inhibition of the $\mathrm{Cl}^{-}$current activated with glycine at its $\mathrm{EC}_{50}\left(\alpha_{1}=27 \pm 3\right.$ and $\left.\alpha_{2}=90 \pm 7 \mu \mathrm{M}\right)$ The agonist was co-applied with tutin during $1 \mathrm{~s}$ at $1 \mathrm{~min}$ intervals at a holding potential of $-60 \mathrm{mV}$. The symbols illustrate the mean \pm SEM for $\alpha_{1}$ (closed circles, $n=8$ ) and $\alpha_{2}$ GlyRs (open circles, $n=5$ ).

inhibitory concentration $(50 \mu \mathrm{M})$ shifted the curve towards the right by $56 \pm 19 \%$ of control (Fig. $2 \mathrm{~A}$, closed triangles, $n=5$ ), while a potentiating concentration $(1 \mu \mathrm{M})$ of tutin had the opposite effect shifting the curve to the left by $33 \pm 7 \%$ (Fig. 2A, closed circles, $n=8$ ). Similar behaviour was observed in $\alpha 2$, where $50 \mu \mathrm{M}$ and $1 \mu \mathrm{M}$ tutin shifted the curve to the right by $30 \pm 5 \%(n=8)$ and to the left by $40 \pm 2 \%(n=9)$, respectively (Fig. 2B).

Application of tutin $(200 \mu \mathrm{M})$ at the peak of the glycine-evoked current showed that its inhibitory effect developed with a fast onset and that it was highly reversible as shown in the original traces in Fig. 3A obtained from homomeric $\alpha 2$ subunit. For instance, the data show that the glycine current recovered to $86 \pm 3.0 \%$ in $\alpha 1$ $(n=5)$ and $90 \pm 3.0 \%$ in $\alpha 2(n=6)$ receptors after tutin application (Fig. 3B). In parallel, the influence of the membrane potential on the

Table 1

Potency of tutin inhibition on different GlyR.

\begin{tabular}{lll}
\hline Receptor subtype & Tutin $(\mu \mathrm{M})$ & PTX $(\mu \mathrm{M})$ \\
\hline$\alpha_{1}$ GlyR & $35 \pm 1(n=8)^{\mathrm{a}}$ & $9^{\mathrm{b}}-18^{\mathrm{c}}$ \\
$\alpha_{1} \beta$ GlyR & $51 \pm 4(n=8)^{\mathrm{a}}$ & $400-1000^{\mathrm{b}-\mathrm{e}}$ \\
$\alpha_{2}$ GlyR & $15 \pm 3(n=6)^{\mathrm{a}}$ & $3^{\mathrm{d}}-6^{\mathrm{b}}$ \\
$\alpha_{2} \beta$ GlyR & $41 \pm 8(n=7)^{\mathrm{a}}$ & $300^{\mathrm{b}, \mathrm{c}}$ \\
\hline
\end{tabular}

${ }^{\mathrm{a}}$ The data summarizes the values of $\mathrm{IC}_{50}$ obtained experimentally in different receptor subtypes. These values were compared with other previously published for blockade with PTX. The $\mathrm{IC}_{50}$ values are expressed as mean \pm SEM in micromolar concentration. $n=$ number of cells studied.

b Pribilla et al., 1992.

c Hawthorne and Lynch, 2005.

d Aguayo et al., 2004.

e Wang-Tilz et al., 2006 
Table 2

Potentiation of recombinant GlyR by tutin.

\begin{tabular}{lll}
\hline Receptor subtype & Maximal tutin potentiation $(\%)$ & Tutin concentration $(\mu \mathrm{M})$ \\
\hline$\alpha_{1}$ GlyR & $30 \pm 3.9^{* * a}$ & 1 \\
$\alpha_{1} \beta_{2}$ GlyR & $18 \pm 5^{* *}$ & 0.03 \\
$\alpha_{2}$ GlyR & $16 \pm 9.7^{* a}$ & 0.03 \\
$\alpha_{2} \beta_{2}$ GlyR & $\mathrm{N} / \mathrm{O}$ & $\mathrm{N} / \mathrm{O}$ \\
\hline
\end{tabular}

${ }^{a}$ The data shows percent of maximal current potentiation induced by low concentrations of tutin on several receptor subtypes. Each value represents the mean \pm SEM of current potentiation at the indicated micromolar concentration. $n=$ number of cells studied $\left({ }^{* *} p<.01 ;{ }^{*} p<0.05\right.$ over the control). NO: not observed.

inhibition of GlyRs was studied at potentials ranging from -60 to $+30 \mathrm{mV}$. Fig. 4 shows current-voltage relationships in both $\alpha 1$ (panel A) and $\alpha 2$ (panel B) GlyRs in the absence (closed squares) and presence (open squares) of tutin $(200 \mu \mathrm{M}, n=8)$. Analysis of the relative inhibition at different membrane potentials showed that tutin produced the same extent of inhibition at all the voltages examined (Fig. 4, insets).

\subsection{Heteromeric $\beta$-containing receptors showed reduced sensitivity to tutin}

The data depicts that $\beta$-containing receptors were less sensitive to inhibition by tutin than their homomeric counterparts (Fig. 5A, Table 1 ). For example, the inhibition of $\alpha_{2} \beta$ had an apparent $\mathrm{IC}_{50}$ of $41 \pm 8 \mu \mathrm{M}$ (Fig. $5 \mathrm{~B}$, open circles, $n=7$ ), while the $\alpha_{1} \beta$ receptor showed an $\mathrm{IC}_{50}$ of $51 \pm 4 \mu \mathrm{M}$ (closed circles, $n=8$ ). Even at a large concentration $(1000 \mu \mathrm{M})$, tutin was unable to fully block the current, especially in $\alpha_{2} \beta$ that showed a resistant component of $19 \pm 5 \%$ of the current amplitude (Fig. 5B). Finally, applications of low concentrations $(0.1 \mathrm{mM})$ to the $\alpha_{1} \beta$ conformation showed a potentiation of $18 \pm 5 \%$ (Fig. 5B, Table 2 ). In the $\alpha_{2} \beta$ conformation, on the other hand, potentiation was not observed.

\subsection{The effect of tutin was not synergistic to those of PTX, ethanol and $\mathrm{Zn}^{2+}$}

Fig. 6A shows the effects of tutin $(1 \mu \mathrm{M})$ and picrotoxin $(0.3$ and $3 \mu \mathrm{M})$ alone or in combination, at concentrations causing submaximal current responses, monitored with propofol, which is a potent allosteric ligand (Yevenes et al., 2008). Data in $\alpha 1$ containing receptors show that picrotoxin caused an even higher diminution of the current than that expected by a simple opposing
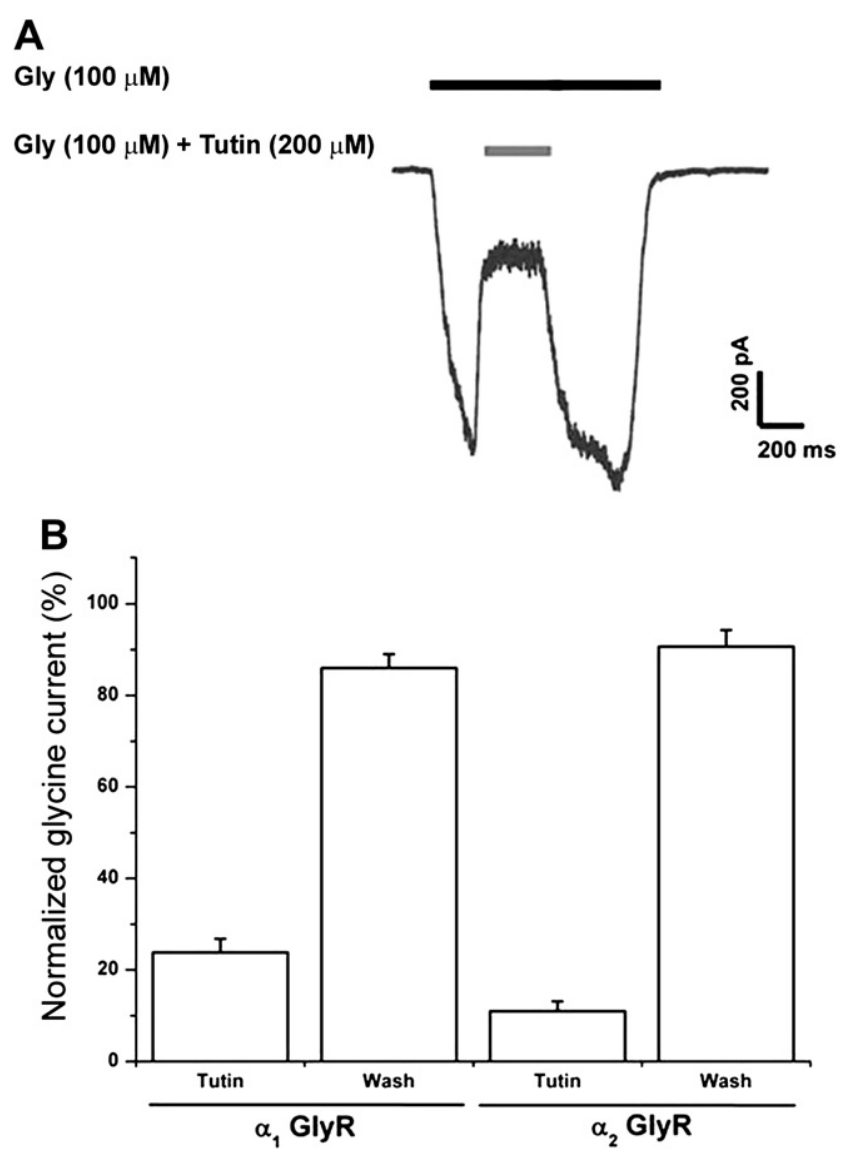

Fig. 3. Reversibility of tutin inhibition on GlyRs. A, the current trace shows onset and recovery from inhibition induced by tutin $(200 \mu \mathrm{M})$ in $\alpha_{2}$ homomeric GlyRs activated with glycine $(110 \mu \mathrm{M})$. Note the full recovery of the current upon removal of tutin. $\mathrm{B}$, the bars show inhibition and reversibility measured after 1 min washout in homomeric $\alpha_{1}(n=6)$ and $\alpha_{2}(n=6)$ GlyRs. Each symbol represents the mean \pm SEM.

mechanism with a potentiating concentration of tutin. Additionally, co-application of tutin $(1 \mu \mathrm{M})$ with a sub-maximal concentration of $\mathrm{Zn}^{2+}(1 \mu \mathrm{M})$ did not produce synergistic effects on $\alpha 1$ (Fig. 6B) or $\alpha 2$ GlyR containing receptors (Fig. 6C). The effects of tutin in two $\alpha 1$ mutants (G254A and R271A), previously described to be resistant to PTX inhibitory actions (Pribilla et al., 1992; Lynch et al., 1995;
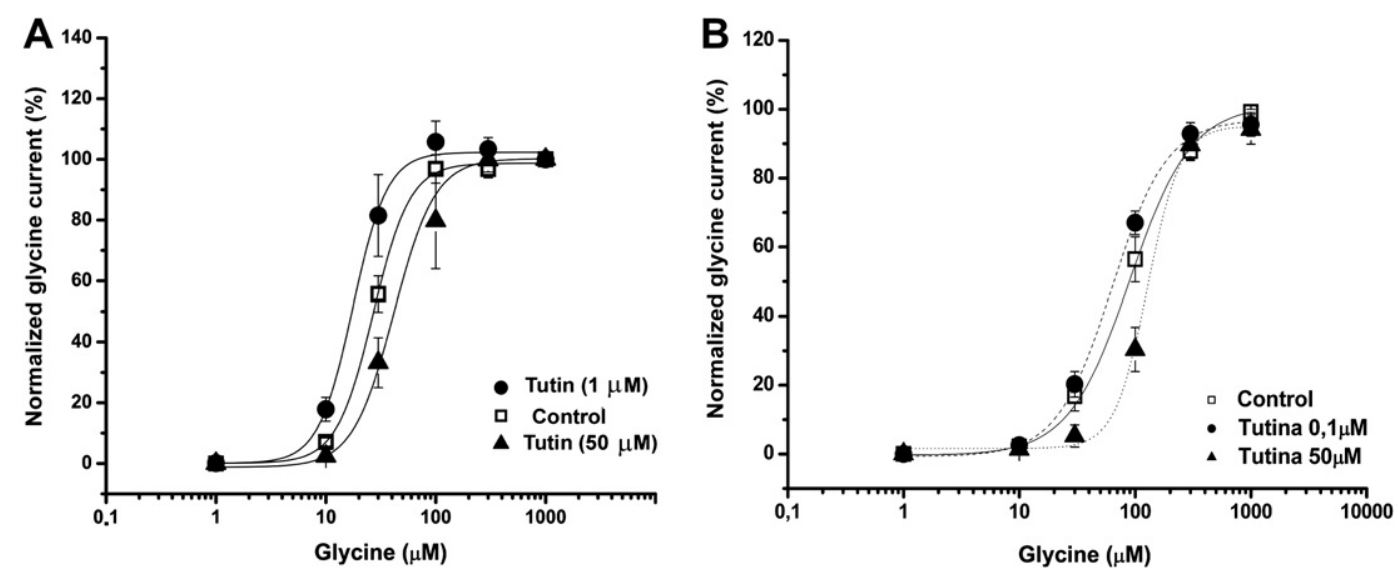

Fig. 2. Effects of tutin concentrations on glycine concentration-response curves. A, the curves represent concentration-response relationships for $\alpha_{1}$ subunit activation induced by different glycine concentrations $(1-1000 \mu \mathrm{M}$ ) without (open squares, $n=5$ ) and co-applied with $1 \mu \mathrm{M}$ tutin (closed circles, $n=8)$ or $50 \mu \mathrm{M}$ tutin (closed triangles, $n=5$ ). $\mathrm{B}$, similar experimental conditions shown in panel A was applied to the $\alpha_{2}$ subunit $(n=7)$. The solid lines were obtained by fitting the data to a single inhibitory site. 
A

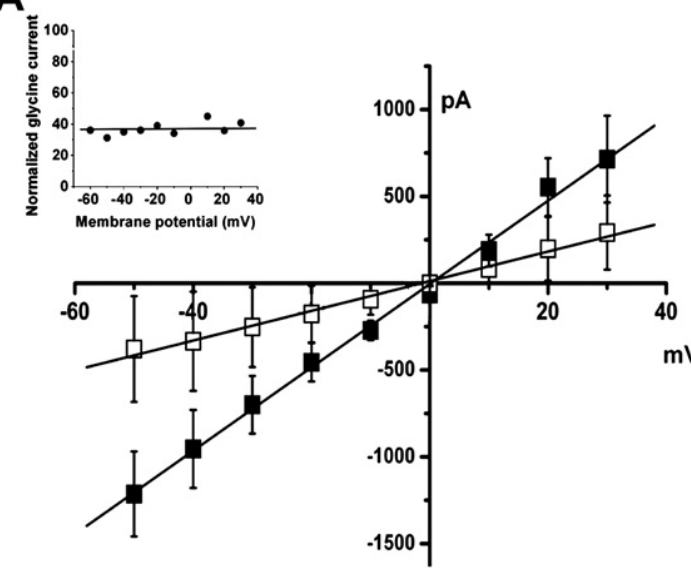

B

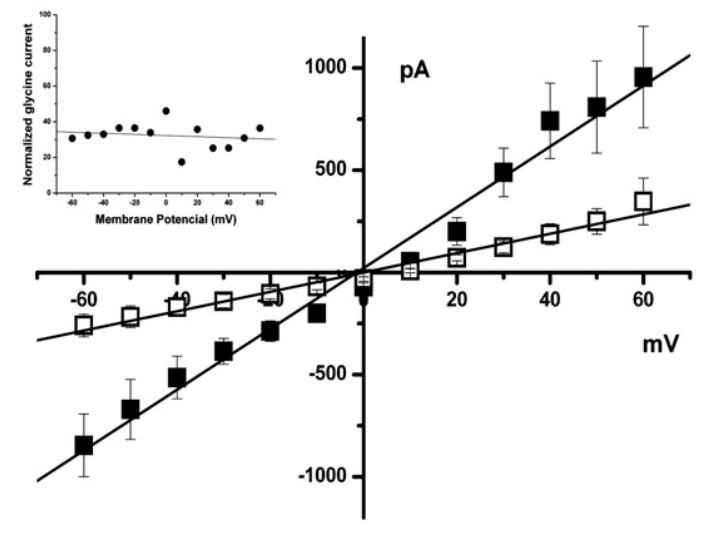

Fig. 4. Voltage-independent inhibition induced by tutin on $\alpha_{1}$ and $\alpha_{2}$ homomeric GlyRs. The voltage-current relationships were obtained in the absence (closed squares) and presence of tutin (200 $\mu \mathrm{M}$, open squares) in $\alpha_{1}$ subunit (panel A) and $\alpha_{2}$ subunits (panel B). The current was activated with $30 \mu \mathrm{M}$ glycine for the $\alpha_{1}$ subunit and $90 \mu \mathrm{M}$ glycine for the $\alpha_{2}$ subunit, at membrane potentials ranging from -60 to $+30 \mathrm{mV}$ with steps of $10 \mathrm{mV}(n=8)$. The inset shows the normalized percentage of inhibition produced by tutin at the different potentials tested. The lines are linear fit to the data $(r>0.99, p<0.0001)$.

Hawthorne and Lynch, 2005; Wang et al., 2007), once again show a high complexity. For example, tutin was unable to potentiate the two mutants (Fig. 6D). In addition, while the G254A became more sensitive to tutin inhibition, the R271A was considerably less sensitive to tutin than the wild type GlyR (Fig. 6D).

In addition, co-application of tutin with ethanol showed a lack of synergism in $\alpha 1$ containing receptors (Fig. 7A). Finally, we examined an ethanol resistant mutant of the $\alpha 1$ glycine receptor (Yevenes et al., 2008) and found that tutin was still able to

\section{A}
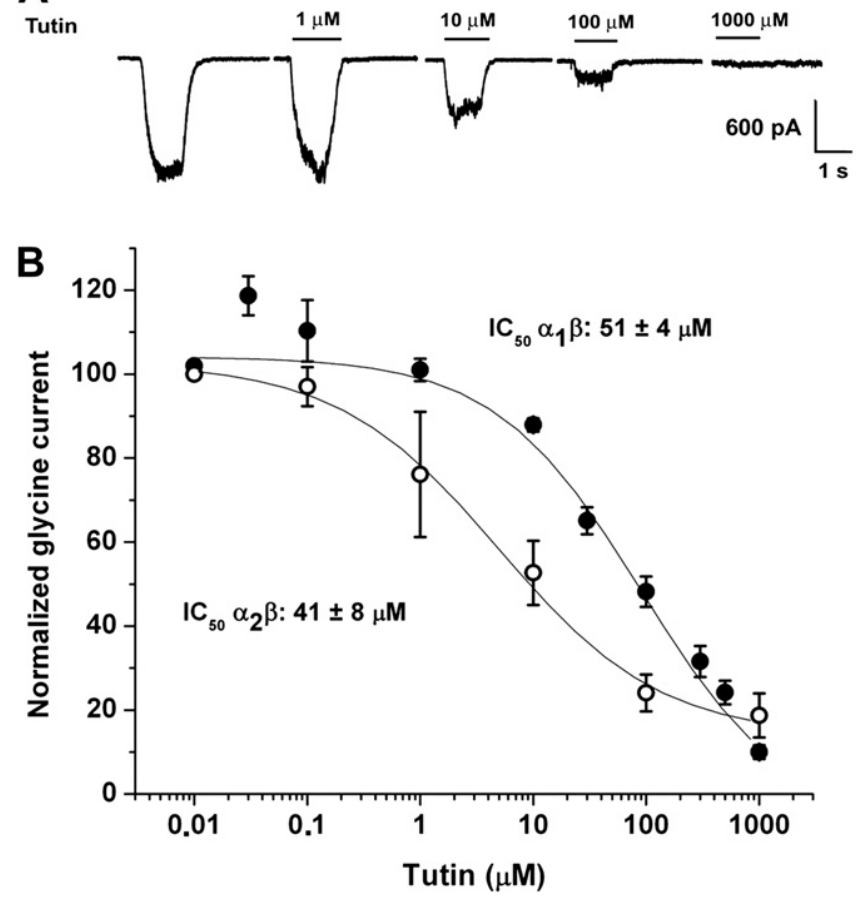

Fig. 5. $\beta$ subunit co-expression reduced the potency of tutin on GlyRs. A, the current evoked in $\alpha_{2} \beta$ GlyRs was inhibited by different tutin concentrations. B, the inhibition curves were obtained in the presence of glycine alone ( $41 \mu \mathrm{M}$ for $\alpha_{1} \beta_{2}$ and $110 \mu \mathrm{M}$ for $\alpha_{2} \beta_{2}$ ) and different concentrations of tutin. The data was obtained in $\alpha_{1} \beta_{2}$ (closed circles, $n=6$ ) and $\alpha_{2} \beta_{2}$ heteromeric GlyRs (open circles, $n=5$ ) Note that $0.03 \mu \mathrm{M}$ tutin induced a small potentiation of the current in $\alpha_{1} \beta_{2}$ GlyRs $(p<0.01)$. potentiate the $\mathrm{K} 385 \mathrm{~A}$ mutant receptor suggesting that tutin and ethanol potentiate GlyRs by different mechanisms.

\section{Discussion}

\subsection{Effects of tutin on recombinant GlyR subunits}

In the present study we characterized the effects of tutin on recombinant glycine receptor subunits. Additionally, these effects were compared with those of PTX because of their structural similarities (Kudo et al., 1984). For example, it was reported that PTX blocks glycine and $\mathrm{GABA}_{\mathrm{A}}$ receptors by complex mechanisms ranging from open channel blockers on $\mathrm{GABA}_{A} \mathrm{Rs}$ to allosteric competitive antagonists on GlyRs (Wang-Tilz et al., 2006). The idea that PTX binds within the channel pore is supported by data showing that the $\alpha 1 \mathrm{R} 271 \mathrm{C}$ mutant, a residue thought to be lying in the pore, is less sensitive to PTX blockade (Etter et al., 1999; Hawthorne and Lynch, 2005). Other studies, in addition, have suggested that PTX also binds additional sites in the GlyR (Wang et al., 2007), including sites at the pore-associated TM2 residues 258 and 254 (Dash et al., 1991; Zhang et al., 1995; Burzomato et al., 2004). We found that the mutations in the TM domains caused complex changes in the inhibitory actions of tutin, but they support the conclusion that the sites for receptor potentiation and inhibition are different.

Tutin inhibited homomeric and heteromeric receptors with different potencies with a ranking of $\alpha_{2}>\alpha_{1}>\alpha_{x} \beta$ for GlyRs. Although the ranking was similar to that of PTX, there were significant differences in their potency values (see Table 1). Also, tutin showed several unique features, as compared to PTX, when blocking inhibitory receptors. Tutin potentiated these receptors at low concentrations. The blocking effect of tutin on the GlyR was competitive, voltage-independent and readily reversible.

The data indicate that the effect of a low concentration was not additive to either $\mathrm{Zn}^{2+}$ or ethanol. This is interesting since despite that these ligands may act at different sites they did not add their effect synergistically (Grudzinska et al., 2005; Yevenes et al., 2008). This can be explained by suggesting that although they attach to distinct positive allosteric sites they cannot enhance channel opening because they affect the pathway between agonist binding and channel gating. Even at a very low concentration of picrotoxin $(0.3 \mu \mathrm{M})$, the effects of these two ligands were not additive and are 
A

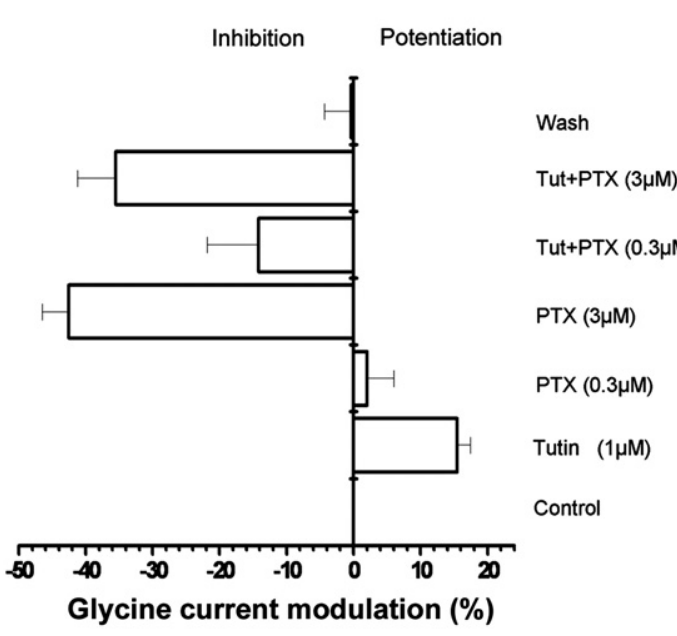

C

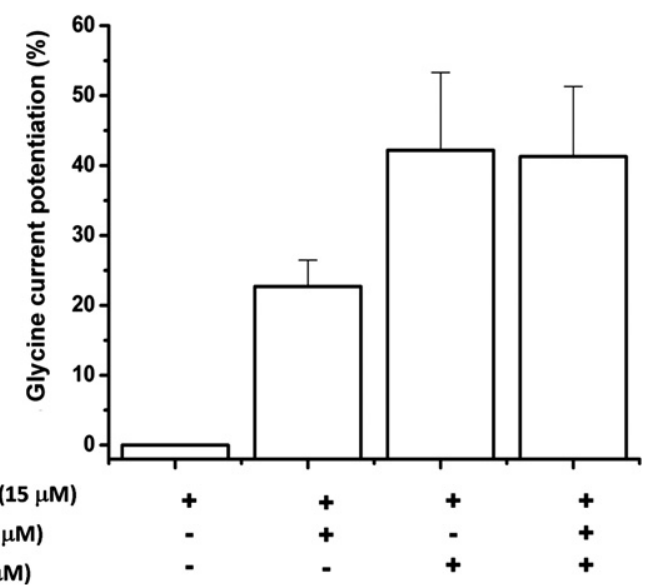

B

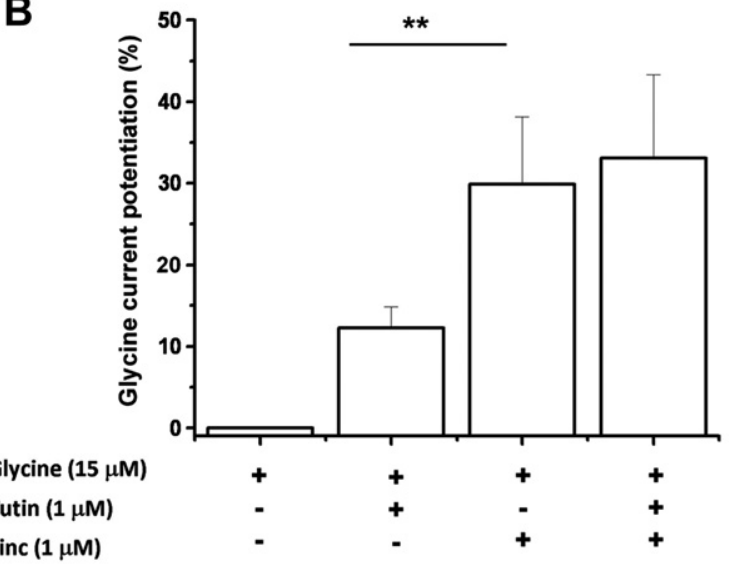

Fig. 6. Effects of tutin alone or co-applied with picrotoxin and $\mathrm{Zn}^{2+}$ on the potentiation of GlyRs. A, effects of potentiating tutin concentrations (1 $\left.\mu \mathrm{M}\right)$ alone and co-applied with picrotoxin at low $(0.3 \mu \mathrm{M})$ and high $(3 \mu \mathrm{M})$ concentrations on $\alpha_{1}$ subunits $(n=8)$. B, action of tutin $(1 \mu \mathrm{M}), \mathrm{Zn}{ }^{2+}(1 \mu \mathrm{M})$ and combination of both on $\alpha_{1}$ GlyRs $\left(n=5\right.$, ${ }^{* *} p<0.01$ tutin vs. $\left.\mathrm{Zn}^{2+}\right)$. C, effects of tutin $(1 \mu \mathrm{M}), \mathrm{Zn}^{2+}(1 \mu \mathrm{M})$ and combination of both on $\alpha_{2}$ GlyRs $(n=6)$. D, action of potentiating tutin concentrations ( $1 \mu \mathrm{M}$, white bar) and inhibiting tutin concentrations ( $50 \mu \mathrm{M}$, black bar) on wild type and G254A and R271A $\alpha_{1}$ mutant glycine receptors. Each bar represents the mean \pm SEM obtained from at least 5 cells $(n=6)$.

suggestive of complex molecular interactions. Thus, the allosteric transduction pathways of glycine and these receptor ligands appear to converge at a common receptor region located prior to channel opening and suggests that they act at a step relevant for extracellular transduction to $\mathrm{Cl}^{-}$ion flux (Lynch et al., 1995).

\subsection{Residues important for agonist binding and modulation}

Glycine binding appears to occur at the interface of two adjacent $\mathrm{N}$-terminal domains and involves residues between $\alpha$ and $\beta$ subunits that are highly conserved (Grudzinska et al., 2005). This is not unique to $\mathrm{Cl}^{-}$inhibitory channels because $\alpha_{4} \beta_{4}$ nACh receptors are also potentiated by interaction of $\mathrm{Zn}^{2+}$ with residues located at alternating $\alpha_{4} \beta_{4}$ interfaces (Hsiao et al., 2006). Similarly, other studies have demonstrated the presence of residues important for the potentiation of GlyRs by extracellular acting ligands. For example, residues D80, E192, D194 contribute to $\mathrm{Cu}^{2+}$ potentiation of $\alpha 1$ GlyRs (Schumann et al., 2009). On the other hand, positions at H107, H109, T112, and T133 are important for receptor blockade by another divalent cation, $\mathrm{Zn}^{+2}$ (Miller et al., 2005a). Additionally, key amino acid residues (R271 and R276) in $\alpha 1$ GlyRs are important for PTX binding and provide information on molecular determinants for receptor blockade (Lynch et al., 1995; Hawthorne and Lynch, 2005; Wang et al., 2007). However, this interpretation is complicated because a single amino acid mutation might not be able to significantly alter the binding site for either PTX or tutin and only systematic mutagenesis studies on these regions will be able to confirm the possibility for binding overlap. However, these studies might be complicated by the changes on gating properties associated to these particular sets of mutations in the TM regions. Furthermore, A254 in GlyRs is important in the binding and inhibitory action of PTX suggesting that this residue might play a role in the inhibitory effects of these compounds (Rundstrom et al., 1994). Similarly, residues near positions $254-261$ in TM2 are important for PTX binding to $\beta_{3}$ subunits in $\mathrm{GABA}_{\mathrm{A}} \mathrm{Rs}$ (Olsen, 2006). In addition, a threonine located at position 246 of the $\beta$ subunit appears to be important since mutation of this residue to phenylalanine abolished the picrotoxin sensitivity on $G_{A B A_{A}}$ receptors (Gurley et al., 1995). Tutin, on the other hand, was still able to induce inhibition in receptors with mutations in residues 254 and 271 of TM2 (Fig. 6B). Additionally, the data supports the idea that the binding residues are not within the pore and could be, similar to $\mathrm{Cu}^{2+}$ and $\mathrm{Zn}^{2+}$, near the glycine binding site (Miller et al., 2005a).

Finally, the effect of tutin was stronger in $\alpha 2$ than in $\alpha 1$ subunits and this is interesting from a toxicological view point since the receptor configuration changes from $\alpha 2 \beta$ to $\alpha 1 \beta$ in the developing central system (Legendre, 2001), providing a potential explanation 
A

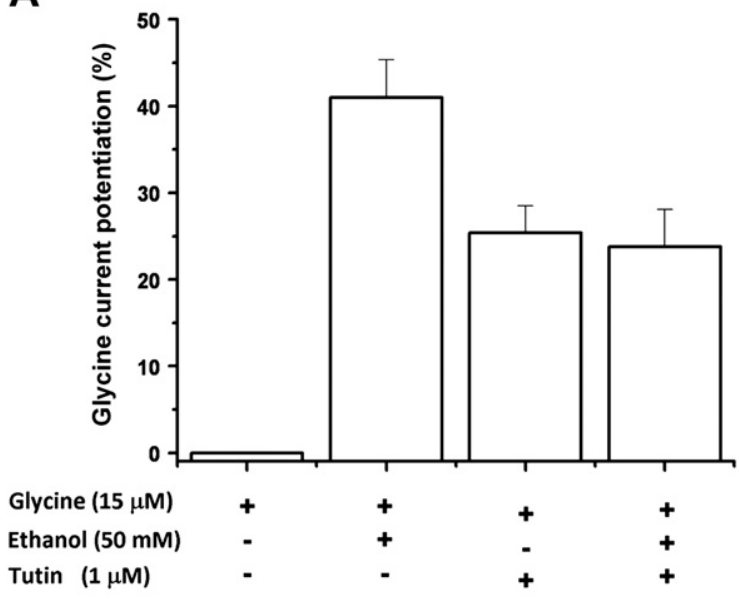

B

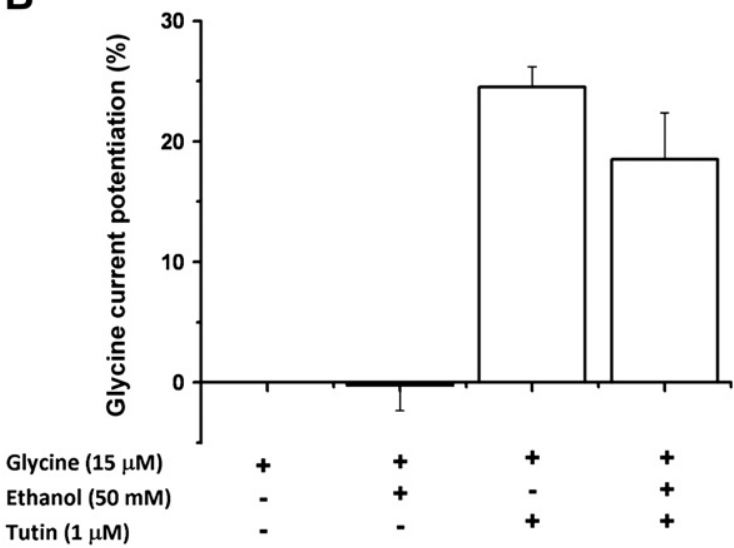

Fig. 7. Effects of tutin applied with ethanol on the potentiation of $\alpha_{1}$ GlyRs. A potentiation of GlyRs by ethanol $(50 \mathrm{mM})$, tutin $(1 \mu \mathrm{M})$ and both combined. B. Effects of ethanol $(50 \mathrm{mM})$, tutin $(1 \mu \mathrm{M})$ and co-application in the K385A mutant $\alpha 1 \mathrm{GlyR}$. Each bar represents the mean \pm SEM obtained from at least 5 cells.

for the larger toxicity of the plant in children (Garcia Martin et al., 1983). Additionally, this study is the first step in finding tutin derivatives that might potentiate inhibitory receptors and therefore be useful as muscle relaxants and pain modulators.

\section{Acknowledgment}

We thank Laurie Aguayo and Claudia Lopez for their technical support. This work was supported by bilateral collaboration of the University of Hasselt Flanders-Chili Innova Bio Bio (05-B1-397L7), DIUC-UdeC (208.033.102.-1.0.), Fondecyt-Iniciacion 11090091, CONICYT ACT 04 and PBCT Nro 7 (Conicyt-World Bank).

\section{References}

Aguayo, L.G., Pancetti, F.C., 1994. Ethanol modulation of the gamma-aminobutyric acidA- and glycine-activated $\mathrm{Cl}^{-}$current in cultured mouse neurons. J. Pharmacol. Exp. Ther. 270, 61-69.

Aguayo, L.G., van Zundert, B., Tapia, J.C., Carrasco, M.A., Alvarez, F.J., 2004. Changes on the properties of glycine receptors during neuronal development. Brain Res. Brain Res. Rev. 47, 33-45.

Akaike, N., Kaneda, M., 1989. Glycine-gated chloride current in acutely isolated rat hypothalamic neurons. J. Neurophysiol. 62, 1400-1409.

Barnard, E.A., Skolnick, P., Olsen, R.W., Mohler, H., Sieghart, W., Biggio, G. Braestrup, C., Bateson, A.N., Langer, S.Z., 1998. International Union of Pharmacology. XV. Subtypes of gamma-aminobutyric acidA receptors: classification on the basis of subunit structure and receptor function. Pharmacol. Rev. 50, 291-313.
Bechade, C., Sur, C., Triller, A., 1994. The inhibitory neuronal glycine receptor. Bioessays $16,735-744$

Betz, H., 1991. Glycine receptors: heterogeneous and widespread in the mammalian brain. Trends Neurosci. 14, 458-461.

Bloomenthal, A.B., Goldwater, E., Pritchett, D.B., Harrison, N.L., 1994. Biphasic modulation of the strychnine-sensitive glycine receptor by $\mathrm{Zn}^{2+}$. Mol. Pharmacol. 46, 1156-1159.

Bormann, J., 2000. The 'ABC' of GABA receptors. Trends Pharmacol. Sci. 21, 16-19.

Burzomato, V., Beato, M., Groot-Kormelink, P.J., Colquhoun, D., Sivilotti, L.G., 2004 Single-channel behavior of heteromeric alpha1beta glycine receptors: an attempt to detect a conformational change before the channel opens. J. Neurosci. 24, 10924-10940.

Cleland, T.A., 1996. Inhibitory glutamate receptor channels. Mol. Neurobiol. 13, 97-136.

Cully, D.F., Paress, P.S., Liu, K.K., Schaeffer, J.M., Arena, J.P., 1996. Identification of a Drosophila melanogaster glutamate-gated chloride channel sensitive to the antiparasitic agent avermectin. J. Biol. Chem. 271, 20187-20191.

Dash, P.K., Karl, K.A., Colicos, M.A., Prywes, R., Kandel, E.R., 1991. cAMP response element-binding protein is activated by $\mathrm{Ca}^{2+} /$ calmodulin- as well as cAMPdependent protein kinase. Proc. Natl. Acad. Sci. U.S.A. 88, 5061-5065.

Etter, A., Cully, D.F., Liu, K.K., Reiss, B., Vassilatis, D.K., Schaeffer, J.M., Arena, J.P., 1999 Picrotoxin blockade of invertebrate glutamate-gated chloride channels: subunit dependence and evidence for binding within the pore. J. Neurochem. 72, 318-326.

Fuentealba, J., Guzman, L., Manriquez-Navarro, P., Perez, C., Silva, M., Becerra, J., Aguayo, L.G., 2007. Inhibitory effects of tutin on glycine receptors in spinal neurons. Eur J. Pharmacol. 559, 61-64.

Garcia Martin, A., Masvidal Aliberch, R.M., Bofill Bernaldo, A.M., Rodriguez Alsina, S. 1983. Poisoning caused by ingestion of Coriaria myrtifolia. Study of 25 cases. An Esp. Pediatr. 19, 366-370.

Grudzinska, J., Schemm, R., Haeger, S., Nicke, A Schmalzing, G., Betz, H., Laube, B. 2005. The beta subunit determines the ligand binding properties of synaptic glycine receptors. Neuron 45, 727-739.

Gurley, D., Amin, J., Ross, P.C., Weiss, D.S., White, G., 1995. Point mutations in the M2 region of the alpha, beta, or gamma subunit of the GABAA channel that abolish block by picrotoxin. Recept. Channel. 3, 13-20.

Hawthorne, R., Lynch, J.W., 2005. A picrotoxin-specific conformational change in the glycine receptor M2-M3 loop. J. Biol. Chem. 280, 35836-35843.

Hoffmann, A.E., 1982. Flora Silvestre de Chile. Zona Austral. Arboles, arbustos y enredaderas leñosas, Santiago, Chile.

Hsiao, B., Mihalak, K.B., Repicky, S.E., Everhart, D., Mederos, A.H., Malhotra, A Luetje, C.W., 2006. Determinants of zinc potentiation on the alpha4 subunit of neuronal nicotinic receptors. Mol. Pharmacol. 69, 27-36.

Janssen, D., Derst, C., Buckinx, R., Van den Eynden, J., Rigo, J.M., Van Kerkhove, E. 2007. Dorsal unpaired median neurons of locusta migratoria express ivermectin- and fipronil-sensitive glutamate-gated chloride channels. J. Neurophysiol. 97, 2642-2650.

Kudo, Y., Niwa, H., Tanaka, A., Yamada, K., 1984. Actions of picrotoxinin and related compounds on the frog spinal cord: the role of a hydroxyl-group at the 6position in antagonizing the actions of amino acids and presynaptic inhibition. Br. J. Pharmacol. 81, 373-380.

Legendre, P., 2001. The glycinergic inhibitory synapse. Cell. Mol. Life Sci. 58, $760-793$.

Lynch, J.W., 2004. Molecular structure and function of the glycine receptor chloride channel. Physiol. Rev. 84, 1051-1095.

Lynch, J.W., 2009. Native glycine receptor subtypes and their physiological roles. Neuropharmacology 56, 303-309.

Lynch, J.W., Rajendra, S., Barry, P.H., Schofield, P.R., 1995. Mutations affecting the glycine receptor agonist transduction mechanism convert the competitive antagonist, picrotoxin, into an allosteric potentiator. J. Biol. Chem. 270, 13799-13806.

Maksay, G., Biro, T., 2005. High affinity, heterogeneous displacement of $\left[{ }^{3} \mathrm{H}\right] \mathrm{EBOB}$ binding to cerebellar GABA A receptors by neurosteroids and GABA agonists. Neuropharmacology 49, 431-438.

Miller, P.S., Beato, M., Harvey, R.J., Smart, T.G., 2005a. Molecular determinants of glycine receptor alphabeta subunit sensitivities to $\mathrm{Zn}^{2+}$-mediated inhibition J. Physiol. 566, 657-670.

Miller, P.S., Da Silva, H.M., Smart, T.G., 2005b. Molecular basis for zinc potentiation at strychnine-sensitive glycine receptors. J. Biol. Chem. 280, 37877-37884.

Muller, E., Le-Corronc, H., Legendre, P., 2008. Extrasynaptic and postsynaptic receptors in glycinergic and GABAergic neurotransmission: a division of labor? Front. Mol. Neurosci. 1, 3.

Newland, C.F., Cull-Candy, S.G., 1992. On the mechanism of action of picrotoxin on GABA receptor channels in dissociated sympathetic neurones of the rat. J. Physiol. 447, 191-213.

Olsen, R.W., 2006. Picrotoxin-like channel blockers of GABAA receptors. Proc. Natl. Acad. Sci. U.S.A. 103, 6081-6082.

Pribilla, I, Takagi, T. Langosch, D. Bormann, J., Betz, $\mathrm{H}$, 1992. The atypical M2 segment of the beta subunit confers picrotoxinin resistance to inhibitory glycine receptor channels. EMBO J. 11, 4305-4311.

Rundstrom, N., Schmieden, V., Betz, H., Bormann, J., Langosch, D., 1994. Cyanotriphenylborate: subtype-specific blocker of glycine receptor chloride channels. Proc. Natl. Acad. Sci. U.S.A. 91, 8950-8954.

Schumann, T., Grudzinska, J., Kuzmin, D., Betz, H., Laube, B., 2009. Binding-site mutations in the alpha 1 subunit of the inhibitory glycine receptor convert the 
inhibitory metal ion $\mathrm{Cu}^{2+}$ into a positive modulator. Neuropharmacology 56, 310-317.

Suwa, H., Saint-Amant, L., Triller, A., Drapeau, P., Legendre, P., 2001. High-affinity zinc potentiation of inhibitory postsynaptic glycinergic currents in the zebrafish hindbrain. J. Neurophysiol. 85, 912-925.

Wang-Tilz, Y., Tilz, C., Wang, B., Tilz, G.P., Stefan, H., 2006. Influence of lamotrigine and topiramate on MDR1 expression in difficult-to-treat temporal lobe epilepsy. Epilepsia 47, 233-239.

Wang, D.S., Buckinx, R., Lecorronc, H., Mangin, J.M., Rigo, J.M., Legendre, P., 2007. Mechanisms for picrotoxinin and picrotin blocks of alpha2 homomeric glycine receptors. J. Biol. Chem. 282, 16016-16035.
Wang, Y., Zhou, D., Wang, B., Li, H., Chai, H., Zhou, Q., Zhang, S., Stefan, H., 2003. A kindling model of pharmacoresistant temporal lobe epilepsy in Sprague-Dawley rats induced by Coriaria lactone and its possible mechanism. Epilepsia 44, 475-488.

Yevenes, G.E., Moraga-Cid, G., Peoples, R.W., Schmalzing, G., Aguayo, L.G., 2008. A selective $G$ betagamma-linked intracellular mechanism for modulation of a ligandgated ion channel by ethanol. Proc. Natl. Acad. Sci. U.S.A. 105, 20523-20528.

Zhang, D., Pan, Z.H., Zhang, X., Brideau, A.D., Lipton, S.A., 1995. Cloning of a gammaaminobutyric acid type $C$ receptor subunit in rat retina with a methionine residue critical for picrotoxinin channel block. Proc. Natl. Acad. Sci. U.S.A. 92, 11756-11760. 